\title{
Search For International Treaty Law on Coronavirus Vaccines/Cure and Chapter IV, IX and $X$ of the UN Charter: Policy and Legal Appraisal
}

\author{
Livinus I. Nwokike \\ Lecturer, Department of International Law and Jurisprudence, Faculty of Law, Nnamdi Azikiwe University, \\ Awka, Anambra State, Nigeria
}

\begin{abstract}
Treaty is one of the sources of international Law. A treaty is an agreement creating binding obligations between subjects of International Law. It has other words that have similar meaning with it; such as convention, protocol, accord, arrangement, understanding, compromise, regulation, provision, pact, charter, statute, act, covenant and so on. The coronavirus disease 19 (COVID-19) is a highly transmittable and pathogenic viral infection caused by severe acute respiratory syndrome coronavirus 2 (SARS-COV-2). Coronaviruses are minute in size and contain a single stranded RNA as a nucleic material, size ranging from 26 to $32 \mathrm{kbs}$ in length. Recently, these viruses have hit the world caused and disrupted many countries political, social and economic programmes without specific vaccine and cure. Having this vaccine should require a law that would regulate its production, establishment, transportation and application at both municipal and international levels. Municipal law is the domestic law of a state regulating the conduct of individuals and legal entities within it while international law is the rules and principles that govern states in their relations interse. Coronavirus pandemic since existence have spread across the globe and therefore, require international treaty to back the administration of the vaccines to people. This paper seeks to examine international law to see if there is any possible treaty that made provision for pandemic like the coronavirus vaccines. It also examines Article 13 of the United Nations Charter to seeing the basis for the UN General Assembly; to find possible vaccine for this pandemic before they make humanity go into extinction. We made possible recommendations for how an offender under the likely treaty can be punished by universal jurisdiction and under the Rome Statute of International Criminal Court. Also, how China and United States of America can bury their hatchet and pass a treaty law on COVID-19 Vaccines under the United Nations. Keywords: Search, International Treaty, Law, Coronavirus, Vaccines, Article 13 and UN Charter.
\end{abstract}

DOI: $10.7176 / \mathrm{JLPG} / 107-02$

Publication date:March $31^{\text {st }} 2021$

\section{Introduction}

Recently, at the end of 2019, Wuhan an emerging business hub of China experienced an outbreak of a novel coronavirus that killed more than eighteen hundred and infected over seventy thousand individuals within the first fifty day of the epidemic. The virus was reported to be a member of the $\beta$ group of coronavirus. The novel virus was named as Wuhan coronavirus of 2019 novel coronavirus $(2019$ - ACOV) by the Chinese researchers (Mohammed Adnan Sheran, Suliman Khan et al, 2021). The strength and wide spread of the coronavirus is without serious abatement by the super powers of the United Nations really gave support to the saying, "human thinking ends where God's own starts." We believe that knowledge of the vaccines to this pandemic was hidden to man to inform man of his limit where God and Natural Law are. The competition between the two super powers of the United Nations; United States of America and China on various issues such as trade, technology, oil and gas and their scramble for Africa also made Nature to hide a simple vaccine for the cure of coronavirus pandemic which is at the verge of making humanity to go into extinction. United Nations should explore every possible effort and strategy to make America and China to bury their hatches to save human beings created by God. The United Nations via their its various agencies should discharge their responsibilities and functions under the United Nations Charter for humanity to be free from this pandemic. United States of America and China have the strength, capability, ability and technology to wrestle this pandemic;if and only if they can come together under the United Nations believing they can resolve and come up with a treaty or convention on vaccine against this minute element called coronavirus. This can only be when they eschew politics, power and technological testing and focus on people oriented policies against COVID-19 Pandemic. Hopefully, Nigeria hope to get COVID-19 Vaccines after February 20, 2021. Thus, "to facilitate pooled procurement and the equitable distribution of COVID-19 Vaccines across developing countries, Nigeria is among 12 countries in Africa that have indicated readiness of the 92 qualified countries for the facility and will by end of February 2021 receive its first shipment of Vaccines (Daily Sun Newspaper, 2021).This is notwithstanding the position of Kogi State Governor who claims that the COVID Vaccines is an agent of death meant to kill people.We believe Article 13 of the UN Charter is instructive and the time for blame game strategy should be over by now. The UN through their agencies can employ alternative dispute resolution and if possible relevant sanctions to achieve this 
objective. They can also adopt universal jurisdiction as a strategy if need be.

\section{Tensions between the US and China Cum Blame Game Strategy}

It was stated that as the world grapples with the human and economic devastation being wrought by the COVID 19 pandemic, not even the relationship between the United States and China is being spared (Michael H Fuchs, 2020).At the time of writing, the number of confirmed cases of COVID-19 passed 600,000, across more than 200 countries and territories. The World Health Organization (the WHO) declared a Public Health Emergency of International concern on 30 January 2020 i.e. an extraordinary event which is serious unusual or unexpected carries transnational implications and many require immediate international action. In quick preparedness and response to the COVID-19 situation, the following actions were taken by WHO:

1. has been in regular and direct contact with Chinese as well as Japanese, Korean and Thai authorities since the reporting of these cases. The three countries have shared information with WHO under the International Health Regulations. WHO is also informing other countries about the situation and providing support as requested;

2. On 2 January, the incident management system was activated across the three levels of WHO (country office, regional office and headquarters);

3. Developed the surveillance case definitions for human infection with 2019-nCoV and is updating it as per the new information becomes available;

4. Developed interim guidance for laboratory diagnosis, clinical management, infection prevention and control in health care settings, home care for mild patients, risk communication and community engagement;

5. Prepared disease commodity package for supplies necessary in identification and management of confirmed patients;

6. Provided recommendations to reduce risk of transmission from animals to humans;

7. Updated the travel advice for international travel in health in relation to the outbreak of pneumonia caused by a new coronavirus in China;

8. Utilizing global expert networks and partnerships for laboratory, infection prevention and control, clinical management and mathematical modelling;

9. Activation of R\&D blueprint to accelerate diagnostics, vaccines, and therapeutics;

WHO is working with our networks of researchers and other experts to coordinate global work on surveillance, epidemiology, modelling, diagnostics, clinical care and treatment, and other ways to identify, manage the disease and limit onward transmission. WHO has issued interim guidance for countries, updated to take into account the current situation (World Health Organization Novel Coronavirus (2019-Cov)). On 11 March, 2020, the WHO declared it a pandemic (http://arbitrationblog.kluwerarbitration.com/2020/03/30/covid19andinvestment-treaty-claim/?print=Pdf).

Measures have been announced by many states on a daily basis to attempt to contain and mitigate the spread of the disease and many have declared states of emergency under their domestic laws. The measures mostly involve social distancing including quarantines, isolation and travel restrictions. These measures have significant human costs, but they are also having a wider impact on economic interests. Europe, Italy, France and Spain, among others have imposed nationwide lockdown and the UK has also imposed significant restrictions on movement. Business are closing across a range of sectors and more are expected over the coming months.

However, the US and China cannot allow their global competition and rising tensions to impede efforts to fight the pandemic. There will be time enough when this global emergency is over to figure out the ways in which the Chineze communist party's (CCP) actions endangered the world by covering up the initial outbreak. But we are where we are, and China, the United States and the rest of the world must focus on fighting the pandemic. Unfortunately, neither the US nor CCP leadership seems willing to resist throwing mud at one another. Thus, at the annual UN general Assembly in New York, the US President Donald Trump blaming China for the spread of coronavirus, he called for China to be held "accountable" for the pandemic. But in swift speech, Chinese President Xi Jinping said his country has "no intention to enter a cold war with any country (https://www.bhc.com/news/world-54253408)."

\section{The Purport of Article 13 of the United Nations Charter}

The General Assembly shall initiate studies and make recommendations for the purpose of:

(a) Promoting international cooperation in the political field and encouraging the progressive development of international law and its codification.

(b) Promoting international cooperation in economic, social, cultural, educational and health field and assisting in the realization of human rights and fundamental freedoms for all without distinction as to race, language or religion and so on (emphasis ours) (Paragraph 1 of Article 13 of the United Nations Charter). 
This should be the basis under which the United Nations can arbitrate into the Vendetta between America and China, settle the differences between them and discharge their responsibility as the health officer of the world using World Health Organization (WHO) as their agent to have nipped this coronavirus pandemic at the bud.

The responsibilities,functions and powers of the General Assembly with respect to matters mentioned in paragraph 1(b) above are set forth in Chapters IX and X (Paragraph 2 of Article 13 of the United Nations Charter).

With a view to the creation of conditions of stability and well-being which are necessary for peaceful and friendly relations among nations based on respect for the principle of equal rights and self-determination of peoples, the United Nations shall promote:

a. higher standards of living, full employment, and conditions of economic and social progress and development.

b. solutions of international economic, social, health and related problems, and international cultural and educational cooperation; and

c. universal respect for and observance of human rights and fundamental freedoms for all without distinction as to race, sex, language or religion (Article 55 of Chapter IX of the UN Charter).

All members pledge themselves to take joint and separate action in co-operation with the Organization for the achievement of the purposes set forth in Article 55 (Article 56 of the United Nations Charter).

The various specialized agencies, established by intergovernmental agreement and having wide international responsibilities, as defined in their basic instruments, in economic, social, cultural, educational, health, and related fields, shall be brought into relationship with the United Nations in accordance with the provisions of Article 63. Such agencies thus brought into relationship with the United Nations are hereinafter referred to as specialized agencies (Article 57of the United Nations Charter).

Responsibility for the discharge of the functions of the Organization set forth in this Chapter shall be vested in the General Assembly and under the authority of the General Assembly, in the Economic and Social Council, which shall have for his purpose the powers set forth in Chapter X(Article 60 of the United Nations Charter).

The Economic and Social Council shall consist of fifty-four Members of the United Nations elected by the General Assembly.

Subject to the provisions of paragraph 3, eighteen members of the Economic and Social Council shall be elected each year for a term of three years. A retiring member shall be eligible for immediate re-election.

At the first-election after the increase in the membership of the Economic and Social Council from twentyseven to fifty-four members, in addition to the members elected in place of the nine members whose term of office expires at the end of that year, twenty-seven additional members shall be elected. Of these twenty-seven additional members, the term of office of nine members so elected shall expire at the end of one year, and of nine other members at the end of two years, in accordance with arrangements made by the General Assembly.Each member of the Economic and Social Council shall have one representative (Article 61 of Chapter X of the UN Charter).

\section{Functions and Powers}

The Economic and Social Council may make or initiate studies and reports with respect to international economic, social, cultural, educational, health, and related matters and may make recommendations with respect to any such matters to the General Assembly to the Members of the United Nations, and to the specialized agencies concerned.

It may make recommendations for the purpose of promoting respect for, and observance of human rights and fundamental freedoms for all.

It may prepare draft conventions for submission to the General Assembly, with respect to matters falling within its competence.It may call, in accordance with the rules prescribed by the United Nations, international conferences on matters falling within its competence(Article 62 of the United Nations Charter).

The Economic and Social Council may enter into agreements with any of the agencies referred to in Article 57, defining the terms on which the agency concerned shall be brought into relationship with the United Nations. Such agreements shall be subject to approval by the General Assembly. It may co-ordinate the activities of the specialized agencies through consultation with and recommendations to such agencies and through recommendations to the General Assembly and to the Members of the United Nations(Article 63 of the United Nations Charter).

The Economic and Social Council may take appropriate steps to obtain regular reports from the specialized agencies. It may make arrangements with the Members of the United Nations and with the specialized agencies to obtain reports on the steps taken to give effect to its own recommendations and to recommendations on matters falling within its competence made by the General Assembly.(Article 64 of the United Nations Charter)It may communicate its observations on these reports to the General Assembly. 
The Economic and Social Council shall perform such functions as fall within the competence in connection with the carrying out of the recommendations of the General Assembly(Article 66 of the United Nations Charter).

It may, with the approval of the General Assembly, perform services at the request of Members of the United Nations and at the request of specialized agencies.

It shall perform such other functions as are specified elsewhere in the present Charter or as may be assigned to it by the General Assembly.However, despite these erudite provisions, one pertinent question is with the political imbroglio between the two super powers of the UN Security Council; America and China, can the General Assembly be allowed to discharge the above responsibilities under the United Nations Charter? Again, could they have summoned peaceful General Assembly and Security Council when Trump (as then American President) and Jin Pinqas Chinese President to come up for resolution cum treaty for the United Nations agency to come up with a common vaccine on coronavirus to save humanity from going to extinction? These are the precis of this paper. They can if politics, countries' interest, technological testing, scramble for Africa, and trade domination world are eschewed and avoided and efforts redoubled against coronavirus pandemic to save first members of the world. We shall kneel down for America and China and can also call on the people of the world to kneel down for United States of America and China if that is what they want for them to come together again to fight COVID-19 head on; for the overall interest of humanity.

\section{Municipal Laws and Law of International Treaty on Coronavirus Vaccine: Any Hope?}

Municipal law simpliciter means the ordinances and other laws applicable within a city, town or other local governmental entity. It is also the internal law of a country as opposed to international law (Garner, 2004). International transactions are normally carried out through treaties. Treaties are called by about thirty different names which include Convention, Protocol, declaration, Charter, Covenant, Pact, Act, Statute, agreement, concordance, modus Vivendi, exchange of notes (or letters) process verbal, final act and general act (Umozurike, 2007). On coronavirus vaccine, countries at national, states and local levels have enacted Laws for the protection of their citizens against coronavirus. But these laws and regulations are mere preventive measures rather than curative measures. That is why countries like Madagascar Institute of Applied Research and that of Bioresources Institute of Nigeria (BION) manufacture of Intercede Health Product (IHP) (Onuoha, 2020) should be encouraged after proper check by the United Nations agency irrespective of their countries and continents. United Nations as an international body should develop their own vaccines and of course, passed a treaty to regulate its usage.

However, care must be taken to ensure that treaty does not conflict with a preemptory norm of general international law. A treaty is void if, at the time of its conclusion, it conflicts with a peremptory norm of general international law (jus cogens). The provisions of such a treaty have no legal force.

If a new peremptory norm of general international law (jus cogens) emerges, any existing treaty which is in conflict with that norm becomes void and terminates. The parties to such a treaty are released from-any obligation further to perform the treaty (United Nations Report of the International Law Commission, 2019).

\section{Commentary}

(1) Draft conclusion 10 concerns the invalidity and termination of treaties on account of being in conflict with peremptory norms of general international law (jus cogens). The invalidity of treaties is the legal effect that is most closely associated with peremptory norms of general international law (Kawasaki, 2006). Article 53 of the 1969 Vienna Convention has rarely been relied upon to invalidate a treaty, so much so that it has been questioned whether it remains operative (Charlesworth and Chinkin). The fact that treaties have rarely been invalidated on account of a conflict with peremptory norms is, however, not because the rule in article 53 is not accepted by States, but simply because States do not generally enter into treaties that conflict with peremptory norms of general international law (jus cogens). Thus, the rule that a treaty in conflict with peremptory norms is invalid continues to be applicable even though it has rarely been applied.

(2) While instances of invalidity of treaties on account of conflict with peremptory norms of general international law (Jus cogens) have been rare, this does not mean that there has been no practice at all that may be relevant to this question. There have been statements made by individual States assessing whether a particular treaty was consistent or not with a peremptory norm of general international law (jus cogens) and, accordingly, whether it could be considered as valid or not (Charter of the United Nations). The General Assembly has adopted resolutions (General Assembly resolution, 1978) which some have interpreted as recognizing that the validity of certain agreements is to be determined by reference to their consistency with certain fundamental principles. There have also been judicial decisions that have considered the invalidity of treaties on account of possible inconsistency with peremptory norms of general international law (jus cogens). In Prosecutor v. TaylorCase No. SCSL-2003-01-I, Decision of 31 May 2004, the Special Court for Sierra Leone had to determine whether the provision in its own Statute which removed immunities of officials was invalid. The Court held that since the provision was "not in conflict with any peremptory norm of general international law, [it] must be 
given effect" to by the Court. It seems to follow that had the provision been in conflict it would not have been given effect to by the Court. Similarly, in the Aloeboetoe, et at. v. Suriname case before the Inter-American Court of Human Rights, reliance had been placed on an agreement concluded between the Netherlands and the Saramaka community for the purposes of reparation (Aloeboetoe and Others v. Suriname, Judgment of 10 September 1993 on Reparation and Costs, Inter-American Court of Human Rights, Series C, No. 15). The Court noted that, under some provisions of the treaty, the Saramaka undertook to capture any escaped slaves and return them to slavery. On that account, the Court held that if the agreement in question were a treaty, it would be "null and void because it contradicts the norms of jus cogens superveniens"

(3) Draft conclusion 10 follows the approach of the 1969 Vienna Convention by distinguishing between, on the one hand, treaties that, at the time of their conclusion, are in conflict with a peremptory norm of general international law (jus cogens) (paragraph 1) and, on the other hand, treaties that conflict with a peremptory norm of general international law that emerges subsequent to the conclusion of the treaty (paragraph 2) (Paragraph (6) of the commentary to article 50 of the draft articles on the law of treaties, Yearbook ... 1966, vol. II, p. 248). The first alternative is addressed in the first sentence of article 53 of the 1969 Vienna Convention white the second alternative is addressed in article 64 of that Convention. Both paragraphs follow closely the text of the 1969 Vienna Convention.

(4) The first sentence of the first paragraph of draft conclusion 10 states simply that treaty is void if, at the time of its conclusion, it conflicts with a peremptory norm of general international taw. The sentence follows, closely the first sentence of article 53. The import of this sentence is that such a treaty is void ab initio. The second sentence of the first paragraph of draft conclusion 10 is taken from the first paragraph of article 69 of the 1969 Vienna Convention and provides that the provisions of a treaty that is invalid on account of being in conflict with a peremptory norm at the time of its conclusion have no legal force.

(5) The second paragraph of draft conclusion 10 concerns the consequences of a newly emerged peremptory norm of general international law on an existing treaty. It states that such a treaty becomes void and terminates. The phrase "becomes void and terminates" indicates that the treaty is not void ab initio but only becomes void at the emergence of the peremptory norm. The treaty becomes void from the moment the norm in question is recognized and accepted as one from which no derogation is permitted. The consequence of the treaty becoming void is that it is only the continuing legal or subsequent legal effects of the provisions of the treaty that terminate. It is for this reason that the second sentence of the second paragraph provides that the parties to such a treaty are released from any obligation further to perform the treaty. This formulation is drawn from article 71, paragraph 2 (a), of the 1969 Vienna Convention. The effect of the text is to recognize that the treaty provisions were valid and could produce legal consequences prior to the emergence of the peremptory norm of general international law (jus cogens). Subject to draft conclusion 12, it is only the obligation to "further" perform that is affected by any termination. Prior to the acceptance and recognition, the rights and obligations under the impugned treaty are fully valid and applicable.

\section{COVID-19 and Investment Treaty Claim}

In these circumstances, states and foreign investors will be considering their positions under applicable investment treaties: will states be insulated for measures taken in response to the emergency presented by COVID-19 or will investors be indemnified for the substantial losses they will have suffer?( Federica Padden and Kafe Parrett, 2020).

If a COVID-19 measure is challenged by a foreign investor, there will be a threshold issue as to whether the measure is potentially in breach of the substantive provisions of an investment treaty. There may be strong ground for a state to contend that the measure adopted is not a breach of fair and equitable treatment or does not amount to indirect expropriation. Provided that it can be established that the measure is incompatible with the relevant obligation, a further question that arises is whether the state has a valid defence to a claim. States can defend against treaty claims by:

1. treaty exceptions; or

2. defences under customary international law. On the application of these under public international law (Paddeu and Jephcott, "COVID-19 and Defences in the Law of State Responsibility Parts I and II", EJIL Talk, 17 March 2020).

\section{Treaty exceptions}

These are expressly set out in the BIT. If the exception applies, the treaty does not apply to the disputed measure. All will depend on the particular treaty.

In early treaties, specific exceptions were rare, although some included exceptions for measures "necessary for the maintenance of public order." One could see an argument to bring some measures taken to combat COVID-19 within the scope of measures for "public order", although ultimately it would depend on the particular circumstances. 
Very few BITs contain general exceptions, or incorporate the general exceptions as set out in the GATT and GATS trade agreements. The general exceptions usually provide that the treaty will not prevent a party from adopting or enforcing measures to protect human life or health, provided that the measures are not arbitrary or discriminatory. Where possible, states are likely to seek to rely on these general exceptions provisions in relation to measures taken in response to COVID-19. This view was supported by a statement made by President Mohamadu Buhari when he posited: "Now is the time to end all forms of restrictions and lockdowns. We cannot kill a million in side to protect 10. As experts have predicted. Coronavirus is not about to disappear even if we lockdown Nigeria for another year. A degeneration of the social anomie is inevitable if there are any further restrictions. It is time to end the hysteria about coronavirus (Mohamadu Buhari, 'COVID-19: Time to Save Economy', Daily Sun Newspaper (Lagos, 22nd January, 2021) at p 7).”

More recent investment treaties have stronger specific exceptions, which explicitly exempt nondiscriminatory regulatory measures for lawful public welfare objectives, including public health, from indirect expropriation obligations. For example, the Canada-EU Trade Agreement (CETA) specifies that nondiscriminatory regulatory measures designed and applied to protect legitimate public welfare objectives, including public health, do not constitute indirect expropriations, except in "rare circumstances." Those may protect states against indirect expropriation claims, but may not assist in relation to breaches of other provision of investment treaties.

Some treaties do go further. For example, the recent China-Australia Free Trade Agreement provides that non-discriminatory measures for "legitimate public welfare objectives of public health... shall not be the subject of a claim" by an investor. Provisions such as these are likely to insulate COVID-19 measures from investment treaty claims.

\section{Customary International Law defences}

Customary international law defences are not set out in the treaty, but have been codified in the ILC Articles on State Responsibility (termed "circumstances precluding wrongfulness"). The treaty continues to apply, but States will be exonerated from any claims for breach for as long as the facts giving rise to the defence continue to exist.

There are six circumstances precluding wrongfulness that are recognized under customary international law: of these, three are potentially relevant to COVID-19 measures:

- force majeure;

- distress; and

- necessity.

This can be explained briefly:

Force Majeure,

A successful claim of force majeure must fulfill five conditions:

1. there must be an unforeseen event or an irresistible force;

2. the event or force must be beyond the control of the state;

3. the event must make it 'materially' impossible to perform an obligation;

4. the state must not have contributed to the situation; and

5. the state must not have assumed the risk of the situation occurring

The plea of force majeure is a strict one, and states have rarely been successful when invoking it. The outbreak of COVID-19 potentially amounts to an unforeseen event or an irresistible force triggering a situation of force majeure, but states are likely to have some difficulty demonstrating material impossibility of performance. This will depend on the specific obligation at issue, and the particular circumstances at play, but in most cases, states are likely to have a choice (even if a difficult one) in respect of compliance.

But note that a rule of customary international law not of a peremptory character ceases to exist if and to the extent that it conflicts with a new peremptory norms of general international law (jus cogens).

The persistent objector rule does not apply to peremptory norms of general international law (jus cogens)(See Conclusion 14 (1) - (3) of the Part Three of the United Nations Report of the International Law Commission Seventy First Session, $29^{\text {th }}$ April $-7^{\text {th }}$ June and $8^{\text {th }}$ July $-9^{\text {th }}$ August, 2019, p. 181).

\section{Distress}

To successfully plead the defence of distress, the state must show:

1. threat to life;

2. a special relationship between the author of the act, whether this is a state organ or an individual whose acts are attributable to the state, and the persons in question;

3. that there was no other reasonable way to deal with the threat;

4. that it did not contribute to the situation; and 
5. that the measures were proportionate.

\section{Necessity}

To successfully plead the defence of necessity, a state must fulfil four requirements:

1. a grave and imminent peril;

2. that threatens an essential interest;

3. the state's act must not seriously impair another essential interest;

4. the state's act was the 'only way' to safeguard the interest from that peril.

In addition, the plea is excluded if:

5. the obligation in question excludes reliance on necessity; and

6. the state contributed to the situation of necessity.

On the basis of publicly available information, it seems arguable that the outbreak and spread of COVID-19 meets the requirement of grave and imminent peril. It is an unfolding event which poses an imminent threat of a grave harm to the world's population.

It also appears arguable that it threatens an essential interest of the State, or of the international community as a whole. The well-being of a States' population and the continued functioning of its public services have been accepted as constituting 'essential interests' in investment treaty arbitration (see National Grid v Argentina).

\section{Conclusion}

COVID-19 Pandemic has come to stay. COVID-19 pandemic have caused death of millions of people across the globe. Treaty is an agreement creating binding obligations between subjects of international law. United Nations through its various strategic agencies on Health should play coordinating roles to work with health organizations and other organizations across the world to develop and produce immediate vaccines and cure to COVID-19. However, hope is not lost. The analysis therefore, shows that at the inception of this pandemic there was no Vaccine, let alone the cure for this virus. Later, some professionals in Nigeria and Africa as mentioned before started to claim the discovery of Vaccine against this pandemic despite some doubt from WHO. Madagascar through their President defiled every obstacles and announced a medicine against COVID-19. Presently, WHO and European governments have doubled their efforts towards meeting the projected vaccination and Vaccine production targets. To this there is imperative need to have agreement that will bind the member states on how to establish, produce, transport, distribute, administer and manage these vaccine if produced among members under international laws to avoid abuse.

WHO as a strong agent of the United Nations has doubled its efforts towards meeting and achieving the projected vaccination and vaccine production targets; to avoid human elimination and extinction. Besides, as European Union government has joined in this effort. Nigerian and African governments should be carried along in this drive. But should be assisted with funds, technologies and equipment in this imperative synergy of saving humanity as they have human capital and professionals towards this target. We believe that God's blessing on innovation and scientific breakthrough can come from any person, country or continent; be it Nigeria, Africa, China, America, United Kingdom and European Union. However, ordinary contract between WHO and any producing company or country on production and administration of these vaccines is not enough. There is need for WHO as the United Nations' strong agent under Article 13 of the United Nations Charter to initiate a treaty or Convention on COVID-19 vaccines. This will create binding legal relations among member states of the United Nations. This, we believe too is the precis of this paper.

\section{Recommendations}

As the rife and blame game strategy between United States of America and China is one of the major problems of confronting peace in the United Nations, efforts should be made by the United Nations to make them bury their hatches in order to fight COVID-19 head on as new government of President Bidenhas come to stay in the United States of America, WHO can freely discharge its responsibilities under the United Nations Charter. This will help the UN General Assembly to discharge their Health functions and responsibility under Article 13, of the Chapter IV, Articles 55, 56, 57 and 60 of Chapter IX and Articles 62, 63, 64 and 66 of Chapter X of the Charter.

The United State of America should rescind its decision against world health organization while the World Health Organization should be made to eschew politics and face their health restricted functions as the UN agency and collate and motivate experts across the globe who have made breakthrough in producing scientifically tested COVID-19 Vaccines and possible cure irrespective of the countries and continent of origin so as to eliminate this pandemic and save humanity from possible extinction.

There is need to increase more financial encouragement on the organizations that promote COVID-19 awareness programs.

COVID-19 treaty should be established enacted and signed by UN member states and serious sanctions and 
punishment provided thereto against erring state(s) member(s).

However, in enacting this COVID-19 treaties, care must be taken to ensure that treaties or rules of customary international law do not conflict with the preemptory norm of general international law (jus cogens). We hereby acknowledge the dogged efforts of some health professionals like Bio Resource Institute of Nigeria (BION), Madagascar Institute of Applied Research, WHO, India, China, United Kingdom, United States of America and European Union Governments for their professional activism and political will against COVID-19 Pandemics. However, more efforts are still needed until we achieve global zero death toll caused by Coronavirus.

\section{REFERENCES}

Aloeboetoe and Others v. Suriname, Judgment of '10 September 1993 on Reparation and Costs, Inter-American Court of Human Rights, Series C, No. 15

Article 55 of Chapter IX of the UN Charter

Article 56 of the UN Charter

Article 57 of the UN Charter

Article 60 of the UN Charter

Article 61 of Chapter X of the UN Charter

Article 62 of the UN Charter

Article 63 of the UN Charter

Article 64 of the UN Charter

Article 66 of the UN Charter

Christ Onuoha, Nigerian Newspaper, Sunday Vanguard of December, 20, 2020, p. 11

Conclusion 10 (1) \& (2) of the Part Three of the United Nations Report of the International Law Commission Seventy First Session, $29^{\text {th }}$ April $-7^{\text {th }}$ June and $8^{\text {th }}$ July $-9^{\text {th }}$ August, 2019, pp. $174-176$.

Conclusion 14 (1) - (3) of the Part Three of the United Nations Report of the International Law Commission Seventy First Session, $29^{\text {th }}$ April $-7^{\text {th }}$ June and $8^{\text {th }}$ July $-9^{\text {th }}$ August, 2019, p. 181.

Danilenko, Law-Making in the International Community, at p. 212 ("As originally conceived., within the codification process relating to the law of treaties, the concept of jus cogens applies only to treaty relationships ... to invalidate bilateral and multilateral agreements contrary to fundamental community rules recognized as 'higher law"')

Federica Paddeu and Kate Parlett COVID-19 and investment Treaty claims, Kluwar Arbitration Blog available on line at http://arbitrationblog.kluwerarbitration.com/2020/03/30/covid-19andinvestment-treatyclaim/?print $=$ Pdf access on $10^{\text {th }}$ December, 2020

Garner, B A, Black's Law Dictionary (United States of America: 10th ed THOMSON REUTERS, 2004) 1176

General Assembly resolution 33/28A of 7 December 1978; General Assembly resolution 34/65 B of 29 November 1979; General Assembly resolutions 36/51 of 24 November 1981; and General Assembly resolution 39/42 of 5 December 1984

Kayode Fayemi, Chairman of Nigerian Governors' Forum about his arrangement with the World Health Organization (WHO), Daily Sun Newspaper (Lagos, 22nd January, 2021) at p 28.

Kleinlein at p. 181; K. Kawasaki, "A brief note on the legal effects of/us cogens in international law", Hitotsubashi Journal of Law and Politics, vol. 34 (2006), p. 27; and den Heijer and vander Wilt at p. 7.

Media caption Trump, Xi Jinping and Guterres address, the UN General Assembly published 22 September, 2020 available online at https://www.bhc.com/news/world-54253408 accessed on 10/12/2020

Michael H Fuchs, The US-China Coronavirus blame game is undermining diplomacy. Available online at https://www.theguardian.com/commentisfree/2020/mar/31/us-china-coronavirus-diplomacy accessed on $10^{\text {th }}$ December, 2020.

Mohamadu Buhari, 'COVID-19: Time to Save Economy', Daily Sun Newspaper (Lagos, 22nd January, 2021) at $\mathrm{p} 7$

Mohammed Adnan Sheran, Suliman Khan et al COVID-19 Infection: Origin, transmission and characteristics of human coronavirus, journal of Advanced research available online at www.elevier.com/locate/jave accessed on 19th December, 2020.

Paddeu, F and Jephcott, F “COVID-19 and Defences in the Law of State Responsibility Parts I and II”, EJIL Talk, 17 March 2020.

Paragraph (6) of the commentary to article 50 of the draft articles on the law of treaties, Yearbook ... 1966, vol. II, p. 248 (draft article 50

Paragraph 1 of Article 13 of the United Nations Charter

Paragraph 2 of Article 13 of the United Nations Charter

Umozurike, U O, Introduction to International Law, Spectrum Books Limited, Ibadan, 2007) 163

World Health Organization Novel Coronavirus (2019-Cov) Situation Report - 21 January, 2020, p. 3 